\section{Lochmaddy}

Alastair Morison, formerly of North Uist and now of Crieff, generously concedes that my picture of Loch Eport ${ }^{1,2}$ was indeed Loch Eport and not Lochmaddy. Of all the sea lochs in the Western Isles, the one I am least likely to misidentify is Lochmaddy. Eighteen years ago I attempted to anchor a large yacht there under sail - our engine was working, but not, unfortunately, the gear box. Wind squally from the west, 25 knots. Out went the anchor and chain, and more and more and more chain, all 60 metres of it. And there, for all on the foredeck to see, the little bit of string that attaches chain to boat, the Bitter End! The only member of the crew not on the foredeck started to pray out loud. I switched mode to Master and Commander-ish and uttered my most melodramatic line in years on boats, 'Pull Men, for our lives depend upon it!!'. This, and a helpful fishing boat, had the desired effect and we were towed into a little tidal gut so secluded that the open sea was invisible. We sat there, stormbound, for 3 days. On the first day the Lochmaddy Hotel had neglected to renew its licence and the bars closed. On return to Glasgow one member of the crew never set foot on a boat again, and another emigrated. So, Lochmaddy, I know thee well!

Time perhaps for the BJGP to seek out new columnists. Potential contributors should send a sample article of 500 words, and outlines of two more to aleclogan@dial.pipex.com. Deadline, end October.

\section{Alec Logan}

\section{REFERENCES}

1. Logan A. Loch Eport. Br J Gen Pract 2010; 60(576): 547.

2. Morrison A. Loch Eport. [letter]. Br J Gen Pract 2010; 60(578): 693.

DOI: 10.3399/bjgp10X532558

\title{
U-turn over NHS Direct
}

Earlier reports that NHS Direct was to be abolished signalled the determination of the new coalition government to implement bold cost-cutting measures to reduce the public sector deficit. Yet, after a brief campaign fronted by former deputy prime minister John Prescott (who has changed his twitter picture to a 'Save NHS Direct' button), and former health ministers Frank Dobson (who launched the service in 1998) and Andy Burnham (trying to raise his profile in the current Labour leadership tussle), health secretary Andrew Lansley has backed down. It turns out that he now merely plans to change the NHS Direct phone number. It appears that the government has belatedly recognised that the symbolic value of the national healthcare advice telephone line is well worth the cost of $£ 123$ million a year.

No doubt Andrew Lansley and his colleagues relished the prospect of striking a blow against the legacy of New Labour by getting rid of NHS Direct, a service celebrated by Tony Blair as the greatest achievement of his first term in office. But NHS Direct serves an even more important function as the most prominent public expression of the therapeutic ethos that is at the centre, not only of the health policies of Labour, but also those of the new coalition government.

GPs have long complained that NHS Direct does nothing to relieve the burden of demand on primary health care (of course, it was introduced, in characteristic defiance of the principles of evidence-based policy, after pilot studies had confirmed this). ${ }^{1}$ Every GP can report cases of misdiagnosis, inappropriate advice, usually amplifying anxieties, and duplicate consultations. Yet these criticisms miss the central point of NHS Direct: its central concern is not with health or health care, but with promoting and reinforcing a new relationship between the state and the individual, through the medium of health.

The great symbolic value of NHS Direct is that it establishes a 'one-toone' link between the post-modern subject, an anxious and fearful person preoccupied by a wide range of threats to health and wellbeing, and a healthcare professional, a proxy for the caring, sharing, feeling prime ministerial role so successfully pioneered by Tony himself (and now faithfully continued by Dave and Nick). The popularity of NHS Direct reflects the high level of individual concern about health matters, the sense of vulnerability to a wide range of environmental dangers (from diverse plagues of infectious disease to climate change), and fears about whichever variety of cancer is currently under the media spotlight. In a more fragmented and individuated society, people experience health anxieties in a particularly intense form and seek reassurance from professional authorities rather than through personal relationships. It is striking that most callers to NHS Direct are young (and female) ${ }^{2}$ and likely to be at low risk of disease. In the official 2001 report promoting NHS Direct as a major achievement and innovation, the Department of Health claimed that it was 'a response to the desire for patient empowerment'. ${ }^{2}$ In his thoughtful new book on his experience of psychosomatic illness, the novelist Tim Parks observes that 'empower' is a verb he dislikes, as 'easy currency for those who tyrannise us with their piety'. ${ }^{3}$ Although the wave of public spending cuts may spare NHS Direct, the pious tyranny it embodies seems set to continue.

\section{REFERENCES}

1. Munro J, Nicholl J, O'Cathain A, Knowles E. Impact of NHS Direct on demand for immediate care: observational study. BMJ 2000; 321:150-153.

2. Department of Health. NHS Direct: a new gateway to healthcare (2nd edition), 2001.

3. Parks T. Teach us to sit still: a sceptic's search for health and healing. London: Harvill Secker, 2010.

DOI: 10.3399/bjgp10X532503 